\title{
Water Quality and Hispathology of Climbing Perch (Anabas testudineus Bloch) at Cempaka Mining, South Kalimantan, Indonesia
}

\author{
R. Yunita (Corresponding author) \\ Graduate Doctor Program, Faculty of Agriculture, Brawijaya University \\ Jln. Veteran, Malang 65145, Indonesia
}

Tel: 62-81-151-8182_E-mail: ryunita65@yahoo.com

\author{
F. H. Yusran
}

Faculty of Agriculture, Lambung Mangkurat University

Jln. A. Yani KM 36, Banjarbaru 70714, Indonesia

E-mail: fhyusran@unlam.ac.id

\author{
U. Yanuhar \\ Faculty of Fisheries and Marine Science, Brawijaya University \\ Jln. Veteran Malang 65145, Indonesia \\ E-mail: uunyanuhar@yahoo.com \\ Y. Risjani \\ Faculty of Fisheries and Marine Science, Brawijaya University \\ Jln. Veteran Malang 65145, Indonesia \\ E-mail: risjani@ub.ac.id
}

Received: July 14, 2013 Accepted: October 24, 2013 Published: January 1, 2014

doi:10.5296/ast.v2i1.4809 URL: http://dx.doi.org/10.5296/ast.v2i1.4809 


\section{Abstract}

The study on water quality and hispathology of climbing perch (Anabas testudineus Bloch) was conducted to analyze water condition, water quality determine the pollution index, and to analyze the liver tissue of the fish in the area of diamond and gold mining areas. Samples were taken from three observation site. The analysis of water quality and fish's liver tissue were conducted in laboratory. Histology observation using the microtechnique method was conducted by preparing histological preparat of climbing perch. Based on classification of water quality, the parameter of alkalinity, mercury $(\mathrm{Hg})$ in liver, Total Suspended Solid(TSS), $\mathrm{Hg}$ in worms, the depth level of site, ammonia $\left(\mathrm{NH}_{3}\right), \mathrm{Hg}$ in snails, Dissolved Oxygen (DO), and $\mathrm{pH}$ were classified into Class $\mathrm{B}$. The pollution index was between $1.0<\mathrm{IP} \leq 5.0$. Therefore, the area of Cempaka diamond and gold mining was mildly polluted. Tissue damage was around 50-80\%. There were severe level types such as inflammation, cloudy swelling, focal necrosis, karyolitic, hemorrhage, and hepatoma.

Keywords: Mercury pollution, Hispathology, Climbing perch 


\section{Background}

The diamond and gold mining activities in Cempaka District have been started long time ago and became a legacy. The most popular mining activities can be found at Murung and Pumpung Village. Those places are tourism objects of diamond mining. Besides diamond, gold has been found in the area and refined using mercury $(\mathrm{Hg})$. $\mathrm{Hg}$ was used to separate gold from fine sands and stones. The mixing process was used in water body or in the house. It was estimated that $5-10 \%$ of $\mathrm{Hg}$ through to the water during the process of mining activities (Lasut, et al., 2010). The use of $\mathrm{Hg}$ has been applied at the mining area of North California USA, separating gold from alluvial soil (Saiki, et al., 2010) and Buyat Bay Indonesia (Lasut, et al., 2010).

Rising gold prices led the gold mining activities continue. The impact to the environment shown by the increase of trees cutting for land opening. Land opening in public area or conservation area threatens the biodiversity. The rehabilitation takes very long time (Howard, et al., 2011; Hammond, et al., 2007; Hilson \& Vieira, 2007; Paterson \& Heemskerk, 2001).

The mining process begins by digging hole which later turns into a lagoon mining pit. When it rains, the water will overflow and enter the lower area, enter the lagoon and swamp around the area. Local fish such as climbing perch that live in the swamp wandering into the lagoon to feed. When the change of seasons, conditions become dry and swamp water began to recede, fish were still looking for a place flooded and headed into the lagoon. Fish trapped in the lagoon during dry season, water temperature ranged from 32.40 to $33.80{ }^{\circ} \mathrm{C}$. No fish were caught in June until September 2012. Climbing perch stress during the dry season as water temperature increased, to make climbing perch exposed to water containing $\mathrm{Hg}$. $\mathrm{Hg}$ was found in the liver of climbing perch from 0.038 to $0.110 \mathrm{mgL}^{-1}$, either in the sediment, the worms, and snails. During the dry season, diamond and gold mining process at Cempaka have an influence on climbing perch and aquatic environments. Results of research on Argentina mining threatens biodiversity, one of the observation station showed toxicological effects on local fish because no fish Brown trout were caught in April 2002 and May 2006 (Carrola, et al., 2009).

Water becomes yellowish dark caused by mining practices. If the water contains $\mathrm{Hg}$, contaminated living things in the water will be consumed by human. The Hg concentration increases from time to time. It is because $\mathrm{Hg}$ is bioaccumulative in nature, therefore harms the environment and human (Shreadah, et al., 2012; Mendil, et al., 2010; Lasut, et al., 2010; Iyabu, 2008; Shastri \& Diwekar, 2008; Scheuhammer, et al., 2007). Water quality with measurement in physics, chemical, and biological parameters has been a standard to determine water quality of an area. It is needed to know water condition, the change of water resource in the quality management and water pollution control. (Ahmed, 2004).

Hispathology analysis can be used as biomarker to investigate fish's health condition through change of liver structure which is the main target of the pollutant (Risjani, et al., 2012; Reddy et al., 2011; Olojo, 2005; Karadede, et al., 2004). Fishes organ can accumulate heavy metal and contribute sensitive indicator from the aquatic pollution. Therefore, it is good to use fish to monitor a water environment. (Risjani, et al., 2012; Reddy, et al., 2011; Akter, et al., 2008; 
Belger \& Rider Forsberg, 2006; Suchcharon \& Lodenius, 1980). Organs which have been successfully used as the hispathology biomarker in the environment observation with $\mathrm{Hg}$ as the main target pollutant are gill, liver, and fish's kidney (Campbell, 2010; Fernandez, et al., 2008; Drevnick, et al., 2008). Those organs are responsible for functionalizing vital activities such as respiration, excretion, accumulation, and poison biotransformation in fish. Based on score of semi quantitative scale, there are four categories of damage level: none, mild, moderate, and severe (Safahieh, et al., 2012; Di Giulio \& Hinton, 2008).

Liver is a vital organ which functions to detoxification and secrete the chemical material used in the digesting process, as well as in the metabolism and transformation of pollutant from the environment. Therefore, liver is an organ which mostly accumulate toxic and easy to be toxically contaminated. Some of the toxic which get into the body after being absorbed by cell will be carried through the liver porta vein to create liver damaged. The existence of $\mathrm{Hg}$ toxic can infect the structure of heart histology of yellowfin seabream (Acanthopagrus latus). It may cause liver pathology such as nuclear degeneration and vacuolation, oncotic, apoptic, focal, massive, cloudy swelling, and other necrosis order (Safahieh et al. 2012). The impact of heavy metal Cd to goldfish's liver (Cyprinus carpio) indicates degenerative change and necrosis during 30 days (Reddy, 2012). Morphology studies on liver bleak fishes (Alburus alburus L), rudd (Scardinus erythrophtalmus L), and perch (Perca fluviatilis L) in 'Student Kladenets' lake, Bulgaria, shows degenerative change, necrosis, and hyperemia (Velcheva, et al., 2010). Liver histology of Ostariophysi, Characidae (Oligosarcus jenynsii) at Los Padres lake, Argentina, shows the same hepatocyte in teleost of freshwater and seawater fish (Petcoff, et al., 2006). The hispathology observation on the brown trout heart (Salmo trutta f. fario) in Tinhela river Portugal shows there is no pathology change $\left(\mathrm{S}_{0}\right)$, the parenchyma shape and stroma is clear. The change of toxipcopathic on $S_{2}$ and $S_{3}$ such as hyperplasia ductus bile, light dysplasia ephitel and adventitial fibrosis arm, the focus of hepatocyte is smaller and more basophilic and necrosis hepatocellular (Carrola, et al., 2009).

Water quality and hispathology as a biomarker can be used to monitor water environment (Risjani, et al., 2012; Kolawole, et al., 2011). The study on inner organ such as fish's liver has an important function in body metabolism which later can be used as prediagnosis to the diagnosis of how damage on fish health starts. (Reddy, et al., 2011; Fernandez, et al., 2008). As the most popular fish in the area, therefore, it is important to monitor the water quality and climbing perch hispathology as biomarker in water environment at diamond and gold mining area at Cempaka District South Kalimantan as well as investigate the fish health through the organ (hispathology) and water quality in the living environment.

\section{Materials and Methods}

\subsection{Study Site}

The determination of sampling place was based on the areas which represent water environment around the mining area. The samples were taken from three site (Figure 1). Site selection was purposive, that certain places were considered important and represent the area sites study conditions. These sites were determined based on the following considerations: a) represents the mouth of the river/lagoon/swamp/pond in the area of artisanal 
miners/traditional and human settlements, b) represents the mouth of the river/lagoon/swamp/pond around former PT Galuh Cempaka diamond and gold mine.

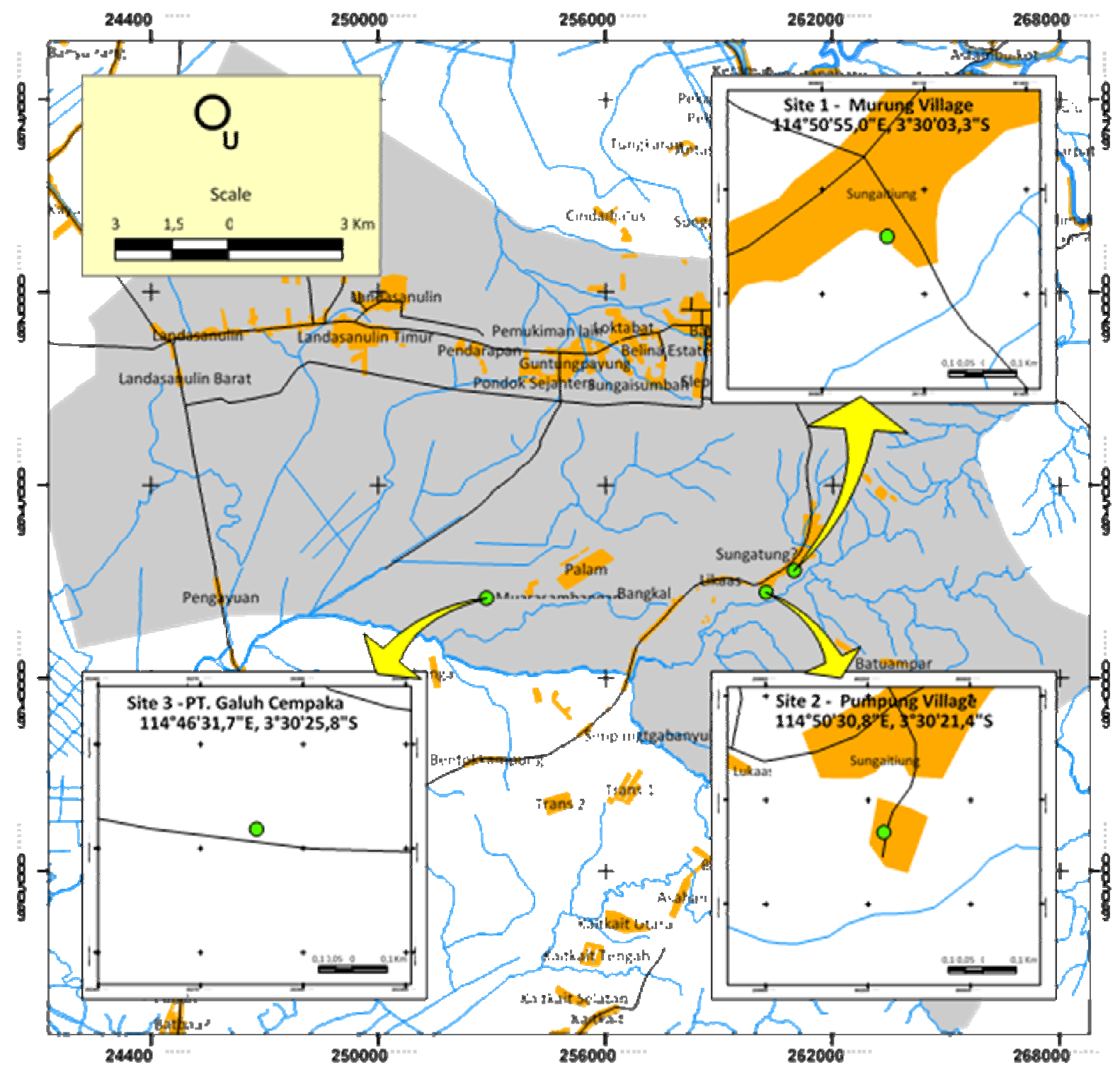

Figure 1. Sampling sites in Cempaka area, Site 1 located at Murung Village, Site 2 at Pumpung Village a traditional diamond and gold mining, Site 3 at PT Galuh Cempaka, a legal inactive diamond and gold mining

\subsection{Physicochemical Parameters}

Physical and chemical parameters were measured, such as temperature, TSS, total dissolved solid (TDS), transparency, depth, $\mathrm{pH}, \mathrm{DO}, \mathrm{NH}_{3}$, alkalinity, biological oxygen demand (BOD), and $\mathrm{Hg}$ in water. Water samples were taken from three different spots. The sampling was done following the criteria of standard and water sampling method (APHA, 1998; Ademoroti, 


\section{Macrothink

1996). The sample was then brought to laboratory for further analyses. TDS and TSS were determined by filtration and evaporation method, transparency using secchi disk and depth was noted directly using roll-meter, while BOD was determined by Winkler titration method (Ademoroti, 1996; APHA 5210 B 2005).

\subsection{Pollution Index}

In order to determine water quality and pollution index, GRME Republic of Indonesia No. $115 / 2003$ was used. The grading system was based on US EPA. Water quality status was determined by using Storet's method by comparing water quality data to water absolute quality matched with the result. The result of analysis on field was compared to the SKGR No. $04 / 2007$ on the absolute quality of liquid waste, SKGR No. 05/2007 on the absolute water quality of river. MHR No. 416/Men.Kes/PER/IX/1990 on water quality criteria and monitoring, and GRRI No. 85/2001 on water quality control and water pollution management.

Pollution index was used to determine level of water quality parameter towards water quality parameter allowed. The pollution index is around $0 \leq \mathrm{IP} \leq 10$ with a criteria matched with the quality standard or good condition up to heavy polluted (GRME, No 115/2003). The determination of water quality status and pollutant index was as stated in GRME No. 115/1003 (in Appendix 2 on the criteria of water quality status determination). To determine the pollution index, mean of all amount was needed $C_{i} / L_{i j}$ as the pollution standard point.

Pollution Index of water is the function of $C_{d} / L_{i j}$, which is:

$$
\mathrm{IP} j=\sqrt{\frac{\left(G_{1} / L_{4}\right) M^{2}+\left(C_{2} / L_{4}\right) R^{2}}{2}}
$$

Where:

$L_{i j}$ : Concentration of physicochemical parameters put on the standard of water denomination (j).

I : Standard of water denomination.

i : Parameter of water quality obtained from water sampling at certain location of sampling on certain river parameter.

$C_{i}:$ Concentration of water quality parameter

$\left(c_{i} / L_{i j}\right) R: C_{i j} L_{t j}$ mean $\left(C_{i} L_{i j}\right) M:\left(c_{t} / L_{t j}\right)$ maximum 


\subsection{Fish Collection and Mercury Analyzer}

Samples of 100 of breeds climbing perch, 100 worms (Lumbricus terrestris), and 100 snails (Pila globosa) were obtained from river or swamp near the mining area. During sampling, the fishermen and local people helped. The tools used were pole line, cast net, hoe, and spade. Abdominal part of the fish was cut and its liver was taken. The liver, snails and worms were then analyzed in laboratory in order to investigate their $\mathrm{Hg}$ content. Determination of $\mathrm{Hg}$ found in fish liver, worms and snails used DMA - 80 Mercury Analyzer (US EPA method 7473).

\subsection{Histology Procedure}

Climbing perch which was considered as being polluted by $\mathrm{Hg}$ was taken and compiled. The cutting was then done to take out the liver. Histology observation using the microtechnique method was conducted by preparing histological preparat of the fish. In order to present the overall liver organ, each sample of liver organ was divided into three frontal parts, median, and distal. The procedure in creating the histological preparat was from Takashima and Hibiya (1995); Haschek et al., (2010). They are fixation, dehydration, clearing, infiltration, embedding, sectioning, affixing, defarafinisation, staining, mounting, and labeling. Observation and calculation of the amount of liver organ cell in tissue was done with binocular microscope Olympus BX41 with 400 times of zooming in and photographing using digital camera Olympus CX21FS1.

There are four categories of damage level based on semi quantitative scale (Di Giulio \& Hinton, 2008; Afshar, et al., 2008; Safahieh, et al., 2012). They are: $(-)=$ none; $(+)=$ mild (achieving 25\% in 1 visual field); $(++)=$ moderate (achieving $50 \%$ in 1 visual field); and $(+++)=$ severe (achieving $75 \%-100 \%$ in 1 visual field). The percentage of organ damage was calculated based on the method used by Kim (2006) :

$$
\text { Damage percentage }=\frac{\text { amoume of ost damaged }}{\text { total amount of amalyged ofl2 }} \times 100 \%
$$

\section{Results and Discussion}

\subsection{Water Quality}

The measurement results of water quality in the area of Cempaka diamond and gold mining at three observation site are shown in Table 1.

From the approximate and average amount of parameter of physicochemical water quality, it is seen that there were differences pictured by the water condition near Cempaka diamond and gold mining area. The explanation of each water quality parameter as follows:

Temperature. Result of temperature measurement showed average temperature of 25.10-33.80 ${ }^{\circ} \mathrm{C}$ at the average of $29.12{ }^{\circ} \mathrm{C}$ (错误！未找到引用源。). It is considered to be in the limit of absolute water quality based on SKGR No. 04/2007 on the absolute quality of liquid waste, SKGR No.5/2007 on absolute water quality of river and MHR No.416/1990 on 
criteria of clean water quality.

Table 1. The average amount of physicochemical parameter and the status of liver tissue of climbing perch

\begin{tabular}{|c|c|c|c|c|c|}
\hline \multirow{2}{*}{ Parameter } & \multirow{2}{*}{ Min - Max } & \multirow{2}{*}{$\begin{array}{l}\text { Mean } \\
\text { SD }\end{array}$} & \multicolumn{3}{|c|}{ Tissue status } \\
\hline & & & fish liver & worm & snail \\
\hline Temperature $\left({ }^{\circ} \mathrm{C}\right)$ & $25.10-33.80$ & $29.12 \pm 4.42$ & visible & damaged & damaged \\
\hline $\mathrm{TSS}\left(\mathrm{mgL}^{-1}\right)$ & $62-143$ & $107.67 \pm 41.47$ & visible & damaged & damaged \\
\hline $\operatorname{TDS}\left(\mathrm{mgL}^{-1}\right)$ & $14-35$ & $25 \pm 10.53$ & visible & damaged & damaged \\
\hline Transparency (cm) & $3-50$ & $21.33 \pm 22.37$ & visible & damaged & damaged \\
\hline Depth (m) & $0.05-30$ & 5 & visible & damaged & damaged \\
\hline $\mathrm{pH}$ & $5.18-6.40$ & $5.73 \pm 0.53$ & visible & damaged & damaged \\
\hline $\mathrm{DO}\left(\mathrm{mgL}^{-1}\right)$ & $0.74-5.10$ & $2.82 \pm 2.11$ & visible & damaged & damaged \\
\hline $\mathrm{NH}_{3}\left(\mathrm{mgL}^{-1}\right)$ & $0.06-3.5$ & $1.75 \pm 1.65$ & visible & damaged & damaged \\
\hline Alkalinity $\left(\mathrm{mgL}^{-1}\right)$ & $14.89-65.29$ & $43.15 \pm 25.75$ & visible & damaged & damaged \\
\hline $\mathrm{BOD}\left(\mathrm{mgL}^{-1}\right)$ & $5.50-16.00$ & $9.97 \pm 5.42$ & visible & damaged & damaged \\
\hline Hg of water $\left(\mu \mathrm{gL}^{-1}\right)$ & $0.001-0.020$ & $0.0005 \pm 0,0820$ & visible & damaged & damaged \\
\hline $\mathrm{Hg}$ of fish liver $\left(\mathrm{mgL}^{-1}\right)$ & $0.002-0.110$ & $0.035 \pm 0.039$ & visible & damaged & damaged \\
\hline $\mathrm{Hg}$ of sediment $\left(\mathrm{mgL}^{-1}\right)$ & $0.001-0.005$ & $0.003 \pm 0.002$ & - & damaged & damaged \\
\hline $\mathrm{Hg}$ of worm $\left(\mathrm{mgL}^{-1}\right)$ & $0.002-0.160$ & $0.058 \pm 0.063$ & damaged & damaged & damaged \\
\hline $\mathrm{Hg}$ of snail $\left(\mathrm{mgL}^{-1}\right)$ & $0.0002-0.1759$ & $0.091 \pm 0.075$ & damaged & damaged & damaged \\
\hline
\end{tabular}

The optimum water temperature for tropical fish to grow is between $25-32{ }^{\circ} \mathrm{C}$ (Boyd \& Lichkoppler, 1991). The first observation was conducted on dry season with high water temperature between $32.40-33.80{ }^{\circ} \mathrm{C}$. Water was low and fish difficult to get because field and swamp were dry. The only water flows was brown and yellowish from the river. It was predicted that if fish swam to pit, they would be trapped for the whole dry season. However, climbing perch are able to adapt to living environment with high temperature and low $\mathrm{O}_{2}$ content. As a result, they grow slowly. Mostly, the length of the fish body is $5.50-10.50 \mathrm{~cm}$, and they weight 13.00-20.60 g. The size does not show balance between body length and weight.

In rainy season, where the temperature back to normal, fish could be found easily near the mining area. They were about $5.20-14.20 \mathrm{~cm}$ and around $10.90-40.45 \mathrm{~g}$ in weight. It seemed that climbing perch grew during the beginning of rainy season. The world climate change will influence the temperature fluctuation in water and will affect growth, reproduction, age, and size of fish (Kuparinen, et al., 2011). Temperature fluctuation may cause stress to goldfish (Cyprinus carpio) and increase cortisol secretion (Takahara, et al., 2011).

Total Suspended Solid (TSS). Result showed that the TSS estimation was around 62-143 $\mathrm{mg} \cdot \mathrm{L}^{-1}$ with an average of $107.67 \mathrm{mg} \cdot \mathrm{L}^{-1}$ (错误! 未找到引用源。). It reached the limit of water absolute quality based on SKGR No. 04/2007 on absolute quality of liquid waste and SKGR No. 05/2007 on absolute water quality of river. 
TSS is needed for fish growth. The TSS needed is between $25-80 \mathrm{mg} \cdot \mathrm{L}^{-1}$ (Alabaster \& Lloyd, 1980). It means that TSS in gold mining area is considered to be bad to support climbing perch growth and other fish's type's cultivation. If fish depend on vision to look for their food in water, the 1-100 mm colloid particles will block their sight. High turbidity may disturb respiration system, aquatic organism's vision, and osmoregulation (Effendi, 2003). Sun light penetration will be blocked if there are too many colloid particles in the water. Photosynthesis system will be slow which may decrease the $\mathrm{O}_{2}$ content in water.

Total Dissolved Solid (TDS). TDS obtained from the laboratory analysis was between 42-35 $\mathrm{mg} \cdot \mathrm{L}^{-1}$ with the average of $25 \mathrm{mg} \cdot \mathrm{L}^{-1}$ (错误!未找到引用源。). The result matched the limit of water absolute quality based on the SKGR No. 04/2007 on absolute quality of liquid waste, SKGR No.05/2007 on absolute water quality of river and MHR No. 416/1990 on the criteria of clean water quality.

Water was yellowish brown and the bottom area could not be seen. It indicated that the level of TSS was higher than TDS. The high turbidity indicated that TSS, with colloidal solidity of $1-10 \mathrm{~mm}$, was found more than TDS with colloidal $<10 \mathrm{~nm}$. The amount of TDS in water was influenced by rocks weathering, runoff, and anthropogenic such as domestic and industrial waste (Effendi, 2003). Dissolved solid consists of inorganic and organic substance, minerals, and also dissolved salts (Alabaster \& Lloyd, 1980). The low amount of TDS indicated that the area of Cempaka gold mining lacked of organic and inorganic substance, minerals, and dissolved salts. However, TDS is not poisonous. The amount of TDS is needed by the living organism in the water and support climbing perch growth. If there is abundance of TDS amount, fish which depend fully on their vision to look for food will be disturbed, blocked by colloidal particles which are $>10 \mathrm{~nm}$ in size. The sun light penetration will be blocked which slow down the photosynthesis process and decrease the $\mathrm{O}_{2}$ content in the water.

Transparency. Transparency measurement predict water depth which allows the sunlight penetrated. The high level of turbidity will influence the level of water transparency. Transparency measurement used secchi disk, reading secchi disk in water and is influenced by phytoplankton and suspended solid in water. The more the amount of phytoplankton in water, the low the water transparency (Gianni, et al, 2012). Result of water transparency measurement and turbidity could be used to find out the assimilation process and the photosynthesis process. The result of measurement on field showed the transparency around 3-50 cm with $21.33 \mathrm{~cm}$ at average. The good water ecosystem for fish is a water which has $\pm 45 \mathrm{~cm}$ of transparency (Boyd \& Lichkoppler, 1991). Climbing perch could live at transparency measured at Cempaka diamond and gold mining area.

Depth. Depth measurement describes transparency level and temperature stratification level in water. There was no difference of temperature level at diamond and gold mining area because the measured depth was still reachable. It was about $\pm 0.05-30 \mathrm{~m}$ at average $5 \mathrm{~m}$ (错 误! 未找到引用源。). Depth of a water influences its temperature. The higher the water depth, the more the temperature level fluctuates (Alabaster \& Llyod, 1980; Michael, 1984). Differences in water depth may cause thermal stratification under water. There were temperature stratification on top layer (epilimnion) of water surface with temperature of \pm 
$30{ }^{\circ} \mathrm{C}$ in depth of $1-2.5 \mathrm{~m}$, thermocline on temperature of $22-28{ }^{\circ} \mathrm{C}$ in depth of $1-1.5 \mathrm{~m}$, hipolimnion in depth of 1.5-2.5 m on temperature of 20-21 ${ }^{\circ} \mathrm{C}$ (Effendi, 2003). At depth of 5-30 $\mathrm{m}$ there was probably temperature stratification. It was because water in pit was similar to lake water where there was water stratification in lake, and temperature difference between water surface and under water.

pH. Result of field measurement at Cempaka diamond and gold mining showed that $\mathrm{pH}$ was around 5.18-6.40 at the average of 5.73 (错误! 未找到引用源。). The result was considered not to match the limit of absolute quality of liquid waste based on SKGR No. 04/2007 on absolute quality of liquid waste and SKGR No. 05/2007 on absolute water quality of river and MHR No. 416/1990 on the criteria of clean water.

The result of filed measurement estimated that $\mathrm{pH}$ under water was acid. If $\mathrm{pH}$ is low or acid in a water, $\mathrm{O}_{2}$ will decrease. Climbing perch can adapt to live in low content of $\mathrm{O}_{2}$. Condition of $\mathrm{pH}$ may affect fish's appetite. At $\mathrm{pH}$ of 5.0-5.5, there will be a decrease of variability and composition of plankton types, periphyton, total abundance, zooplankton biomass, resistance of nitrification process, much benthos, and more filament of green alga (Effendi, 2003). Appropriate $\mathrm{pH}$ for living things under water is around 6.3-9.0. Usually, the average of 6.5-8.6 is good for fish to grow (Alabaster \& Lloyd, 1980).

Dissolved Oxygen (DO). Result of dissolved $\mathrm{O}_{2}$ measurement in water near Cempaka diamond and gold mining area was around $0.74-5.10 \mathrm{mg} \cdot \mathrm{L}^{-1}$ with average of $2.82 \mathrm{mg} \cdot \mathrm{L}^{-1}$ (错误！未找到引用源。).The result was considered to be not appropriate with the limit of absolute water quality based on SKGR No.05/2007 on river water absolute quality.

$\mathrm{O}_{2}$ content is defined as DO in a water needed by living organisms in the water. There was not much soluble $\mathrm{O}_{2}$. The result of phytoplankton respiration and other water plants produced high $\mathrm{O}_{2}$ and $\mathrm{pH}$. Fish do not like water which lacks of $\mathrm{O}_{2}$. Therefore, it was difficult to get fish because they have left the area to get a better habitat. In the end of the research (February-April), DO was around $4.40-5.10 \mathrm{mg} \cdot \mathrm{L}^{-1}$ meaning that it is $3 \mathrm{mg} \cdot \mathrm{L}^{-1}$, the water condition was getting better. Fish got in the water area of mining gold and they were starting to grow. Small fish was found. The size was around $5.50-10.50 \mathrm{~cm}$ and weighed about 13-20.60 g. This fact indicated that in the end of the research more fish and plants lived in the water near diamond and gold mining area. DO in water needed for fishes growth is around 3 $\mathrm{mg} \cdot \mathrm{L}^{-1}$ (Boyd \& Lichkoppler, 1991). Soluble $\mathrm{O}_{2}$ content to support the life of aquatic biota should be about $\pm 5 \mathrm{mg} \cdot \mathrm{L}^{-1}$ (Alabaster \& Lloyd, 1980; Effendi, 2003). DO content in water which is considered good to support life of tropical fish should be at least $6 \mathrm{mg} \cdot \mathrm{L}^{-1}$ (OATA, 2008). In minimum, DO concentration in water is noted at $7 \mathrm{am}$, while the maximum content is noted at $5.30 \mathrm{pm}$ (You, et al., 2007; Cui, et al., 2008).

Ammonia $\left(\mathbf{N H}_{3}\right)$. Result of $\mathrm{NH}_{3}$ measurement in the area of gold mining was between 0.06-3.5 mg. $\mathrm{L}^{-1}$ with an average of $1.75 \mathrm{mg} \cdot \mathrm{L}^{-1}$ (错误! 未找到引用源。). The result indicated that the content did not achieve the absolute limit of water quality based on SKGR No. $04 / 2007$ on the absolute quality of liquid waste, SKGR No.05/2007 on the absolute water quality of river. 
$\mathrm{NH}_{3}$ and its salt are soluble in water. $\mathrm{NH}_{3}$ comes from un-compounding of the organic- and inorganic-N. Organic-N is obtained from protein and urea, while inorganic-N found in soil and water is made of decomposition of organic material such as dead plants and aquatic biota. Rehabilitating process is called ammonification (Effendi, 2003). Measured $\mathrm{NH}_{3}$ in water is total $\mathrm{NH}_{3}\left(\mathrm{NH}_{3}\right.$ and $\left.\mathrm{NH}_{4}\right)$. Free $\mathrm{NH}_{3}$ cannot be ionized, while ammonium $\left(\mathrm{NH}_{4}{ }^{-}\right)$can be ionized. Free $\mathrm{NH}_{3}$ which cannot be ionized tends to be toxic to aquatic organism. Level of poison of $\mathrm{NH}_{3}$ to the aquatic organism will increase if DO decreases, $\mathrm{pH}$, and temperature (Michael, 1984; Alabaster \& Lloyd, 1980).

Tropical fish needs healthy water to live and should have $\mathrm{NH}_{3}$ content around $0.02 \mathrm{mg} \cdot \mathrm{L}^{-1}$ (OATA, 2008). $\mathrm{NH}_{3}$ content around 0.4-3.1 $\mathrm{mg} \cdot \mathrm{L}^{-1}$ may cause death to fish (Boyd \& Lickoppler, 1991). Death may happen when $\mathrm{NH}_{3}$ concentration is about $\pm 0.5 \mathrm{mgL}^{-1}$ and the DO content is around $6 \mathrm{mg} \cdot \mathrm{L}^{-1}$. If DO content is $\pm 0.2 \mathrm{mg} \cdot \mathrm{L}^{-1}$ and $\mathrm{NH}_{3}$ content is around \pm 0.2 $\mathrm{mg} \cdot \mathrm{L}^{-1}$, the environment will harm the fish and can cause death. Death on fish species varies, acute level of death is around $0.2-2.0 \mathrm{mg} \cdot \mathrm{L}^{-1}$ (Alabaster \& Lloyd, 1980). Good environment for fish should contain $0.02 \mathrm{mg} \cdot \mathrm{L}^{-1}$ of free $\mathrm{NH}_{3}, 0.2 \mathrm{mg} \cdot \mathrm{L}^{-1}$ of $\mathrm{NO}_{2}$ and $50 \mathrm{mg} \cdot \mathrm{L}^{-1} \mathrm{NO}_{3}$ in maximum (OATA, 2008).

Alkalinity. Result of alkalinity measurement in gold mining area was around 14.89-65.29 $\mathrm{mgL}^{-1}$ with an average of $43.15 \mathrm{mg} \cdot \mathrm{L}^{-1}$ (错误！未找到引用源。). It meant that the alkalinity suited the criteria of good media which have $2-300 \mathrm{mg} \cdot \mathrm{L}^{-1}$ of alkalinity and hardness (Boyd, 1988). The optimum alkalinity in intensive fish cultivation is around $100-150 \mathrm{mg} \cdot \mathrm{L}^{-1}$ (Wedenmeyer, 1996). Much research report that there were negative correlations between alkalinity and $\mathrm{Hg}$ in fish tissue (Driscoll, et al., 2007).

Alkalinity is considered to be a buffer capacity towards $\mathrm{pH}$ change in water (Davis \& Masten, 2004). The higher the alkalinity, the higher the ability of water to buffer which therefore makes the $\mathrm{pH}$ fluctuation decrease. Mostly, in fresh water, alkalinity is formed by bicarbonate and carbonate which are around $72.4 \%$ (Effendi, 2003). Alkalinity is usually mentioned in $\mathrm{mg} \cdot \mathrm{L}^{-1}$, while $\mathrm{CaCO}_{3}$ is usually mentioned in $\mathrm{CaCO}_{3} \cdot \mathrm{CaCO}_{3}$ is defined as substance which gives biggest contribution to the alkalinity and hardness in water. Big amount of $\mathrm{CaCO}_{3}$ is found in soil. Therefore, the content in freshwater is considered to be high. The absorbance of $\mathrm{CaCO}_{3}$ decreases as temperature and $\mathrm{CO}_{2}$ increases (Effendi, 2003). Appropriate content of alkalinity in water should be around $30-500 \mathrm{mgL}^{-1} \mathrm{CaCO}_{3}$. Alkalinity in natural water is \pm 40 $\mathrm{mg} \cdot \mathrm{L}^{-1}$ (Boyd, 1988). Water which has alkalinity of $>40 \mathrm{mg} \cdot \mathrm{L}^{-1} \mathrm{CaCO}_{3}$ is defined as hard water, while water which has $<40 \mathrm{mg} \cdot \mathrm{L}^{-1} \mathrm{CaCO}_{3}$ of alkalinity is defined as soft water.

Biochemical Oxygen Demand (BOD). Result of Cempaka BOD was around 5.50-16.00 $\mathrm{mg} \cdot \mathrm{L}^{-1}$ at average $9.97 \mathrm{mg} \cdot \mathrm{L}^{-1}$ (错误! 未找到引用源。). It was considered to match the limit of absolute quality material based on the SKGR No.04/2007 on absolute quality of liquid waste and SKGR No. 05/2007 on absolute water quality of river. BOD at Site 2 and Site 3 was under the limit of absolute water quality and suited the criteria of absolute river water quality. BOD at Site 1 was found to be above the limit of absolute quality of water and did not achieve the criteria of absolute water quality of river. BOD is some amount of $\mathrm{O}_{2}$ needed by microorganism to decompose organic material. BOD measurement is needed to monitor 
organic material which cannot be easily decomposed. Therefore, BOD is defined as organic pollution indicator (Mandal, et al., 2010).

Mercury (Hg) of water. Result of $\mathrm{Hg}$ measurement was around $0.001-0.02 \mu \mathrm{g} \cdot \mathrm{L}^{-1}$ with average of $0.0005 \mu \mathrm{g} \cdot \mathrm{L}^{-1}$ (错误！未找到引用源。) which was on the limit of absolute quality based on GRRI No. 82/2001 on the management of water quality and water pollution control. Concentration of $\mathrm{Hg}$ at some gold mines in Canada showed about $0.002-0.00008 \mathrm{mgL}^{-1}$ of $\mathrm{Hg}$ which was still under the absolute quality of (NRC, 1996; 1998).

In majority, $\mathrm{Hg}$ in water is inorganic form around \pm 95-99 \% (Krabbenhoft, 1996). The form of ion from organic and inorganic salt is much found in the water. In the water, organic and inorganic ion will react with other substance or be absorbed by water plants and animal. Inorganic $\mathrm{Hg}$ is conversed to methyl mercury $\left(\mathrm{CH}_{3} \mathrm{Hg}^{+}\right)$by microorganism. $\mathrm{CH}_{3} \mathrm{Hg}^{+}$is a substance which is very poisonous and very absorbable to tissue.

Mercury (Hg) of sediment. Result of $\mathrm{Hg}$ sediment was around $0.001-0.005 \mathrm{mg} \cdot \mathrm{L}^{-1}$ with average $0.003 \mathrm{mg} \cdot \mathrm{L}^{-1}$ (错误! 未找到引用源。). The amount of $\mathrm{Hg}$ in sediment, in order to support growth and life of living things, should not be more than $0.4 \mathrm{mg} \cdot \mathrm{L}^{-1}$ (Turekian \& Wedepohl, 1961). The amount of $\mathrm{Hg}$ in sediment at Cempaka gold mining area was still under the absolute quality of water. Generally, $\mathrm{Hg}$ in sediment does not have direct implication to human health as long as the sediment is not directly consumed by human. However, there is serious consequence if $\mathrm{Hg}$ enters the food chain (Nartey, et al., 2011). $\mathrm{Hg}$ sediment in soil is around $40-200 \mathrm{ng} \cdot \mathrm{g}^{-1}$, in form of Cinnabar $(\mathrm{HgS})$. It is very reactive to environment (Davies, et al., 1997). $\mathrm{Hg}$ measurement in the sediment was conducted to find out the existence of $\mathrm{Hg}$ naturally. It was considered that gold mining activity at Cempaka increased $\mathrm{Hg}$ content.

Mercury (Hg) of climbing perch. Bioaccumulation of $\mathrm{Hg}$ through food chain plays important part in deciding $\mathrm{Hg}$ capacity in fish body. It is because of the accumulative characteristics of $\mathrm{Hg}$ (Hall, et al., 1997). The total of $\mathrm{Hg}$ in internal organ such as liver and the whole body of fish may vary among fish. Perhaps it represents physiological differences between different tropical groups (Altun, et al., 2009). Generally, fishes was defined as bad environment contaminant and was being studied for the sake of food safety. Level of $\mathrm{Hg}$ on fresh water and sea water must be conducted as an intensive monitoring in order to protect human from $\mathrm{Hg}$ poisoning (Sary \& Maryam, 2012).

The absorbed $\mathrm{Hg}$ from food enters tissue through blood. In soft tissue such as fish's liver and kidney, $\mathrm{Hg}$ will be detected (Hall, et al., 1997). Hg would increases continuously because there was not much $\mathrm{Hg}$ metal secreted by system excretion of fish (Kalay dan Camli, 2000). The measurement of $\mathrm{Hg}$ content in climbing perch liver is around $0.002-0.110 \mathrm{mgL}^{-1}$ at average $0.035 \mathrm{mg} \cdot \mathrm{L}^{-1}$ (错误！未找到引用源。). Hg content in liver tissue of climbing perch Site 1 at Murung Village was $0.038 \mathrm{mg} \cdot \mathrm{L}^{-1}$, while $\mathrm{Hg}$ content at Site $3 \mathrm{PT}$. Galuh Cempaka was $0.110 \mathrm{mg} \cdot \mathrm{L}^{-1}$. The $\mathrm{Hg}$ content in fish and other aquatic organisms will be not more than $0.033 \mathrm{mg} \cdot \mathrm{L}^{-1}$ (CCME, 2000). The measured $\mathrm{Hg}$ content lately has passed the allowed $\mathrm{Hg}$ content in aquatic biota. In other words, it is more than $0.033 \mathrm{mg} \cdot \mathrm{L}^{-1}$. 


\section{MInstitute Macrothink $_{\text {Int }}$}

Mercury (Hg) of worm. Hg content in worm was measured to see difference of $\mathrm{Hg}$ amount in vertebrate and invertebrate at gold mining area. The result of measurement at field showed that $\mathrm{Hg}$ content in worm was around $0.002-0.160 \mathrm{mg} \cdot \mathrm{L}^{-1}$ at average $0.058 \mathrm{mg} \cdot \mathrm{L}^{-1}$ (错误!未找 到引用源。). $\mathrm{Hg}$ content in fish and other aquatic organisms will be appropriate if it is not more than $0.033 \mathrm{mg} \cdot \mathrm{L}^{-1}$ (CCME, 2000). Some of $\mathrm{Hg}$ content in worm, at Site 2, were under the limit of quality, while the rest, at Site 1, did not suit the allowed criteria. At Murung Village or Site 1, the $\mathrm{Hg}$ content in worm was about 0.057 and $0.160 \mathrm{mg} \cdot \mathrm{L}^{-1}$. It had passed the allowed amount which should not more than $0.033 \mathrm{mg} \cdot \mathrm{L}^{-1}$ (CCME, 2000). The monitoring of $\mathrm{Hg}$ content in worm body tissue is needed to be done. It is because there have been detected Hg content in worm's tissue lately. Worm was not found at Site 3 (PT Galuh Cempaka). Probably, water contained $\mathrm{Hg}$ or other heavy metal content which harmed the worms. As a consequence, there was not any worm found in soil. The only type of plant found around mining pit was Fimbristylis globulosa.

Mercury (Hg) of snail. $\mathrm{Hg}$ content in snail was measured to see the difference of $\mathrm{Hg}$ content in vertebrate (fish) and invertebrate (worm, snail) at gold mining area. The result of field measurement showed that $\mathrm{Hg}$ content in snail was around $0.013-0.176 \mathrm{mg} \cdot \mathrm{L}^{-1}$ at average $0.091 \mathrm{mg} \cdot \mathrm{L}^{-1}$ (错误! 未找到引用源。). $\mathrm{Hg}$ content in fish and other aquatic organism should not more than $0.033 \mathrm{mg} \cdot \mathrm{L}^{-1}$ (CCME, 2000). Some of $\mathrm{Hg}$ content in snail at Site 2 were under the limit of absolute quality, while some at Site 1 and 3 did not suit the allowed criteria. $\mathrm{Hg}$ content in snail at Site 1 at Murung Village was about $0.079 \mathrm{mg} \cdot \mathrm{L}^{-1}$ and $0.169 \mathrm{mg} \cdot \mathrm{L}^{-1}$, while at Site 3, it was around $0.111-0.177 \mathrm{mg} \cdot \mathrm{L}^{-1}$. The amount was considered to be more than the allowed amount, which was more than $0.033 \mathrm{mg} \cdot \mathrm{L}^{-1}$. $\mathrm{Hg}$ monitoring in snail's tissue is needed to be done because there have been detected that $\mathrm{Hg}$ exists in worm's and snail's tissue.

\subsection{Determination Pollution Index}

Determination of water quality status can be done by discovering the pollution index towards of physicochemical parameters. Pollution index from the measured quality at each site at field can be seen in Table 2 .

Table 2. Pollution index at Cempaka mining area

\begin{tabular}{lllll}
\hline No & Parameter & $\left(\mathbf{C}_{\mathbf{i}} / \mathbf{L}_{\mathbf{i j}}\right)^{\mathbf{2}}$ at Mean & $\left(\mathbf{C}_{\mathbf{i}} / \mathbf{L}_{\mathbf{i j}}\right)^{\mathbf{2}}$ Maximum & $\mathbf{I P}_{\mathbf{i j}}$ \\
\hline 1. & Temperature $\left({ }^{\circ} \mathrm{C}\right)$ & 0,59 & 0,62 & 0,77 \\
2 & $\mathrm{TDS}\left(\mathrm{mg} \cdot \mathrm{L}^{-1}\right)$ & 0,00 & 0,00 & $0,50 \times 10^{-2}$ \\
3 & $\mathrm{Hg} \mathrm{of} \mathrm{water}\left(\mu \mathrm{g} \cdot \mathrm{L}^{-1}\right)$ & 0,00 & 0,00 & 0,00 \\
4 & $\mathrm{Hg}$ of sediment $\left(\mathrm{mg} \cdot \mathrm{L}^{-1}\right)$ & $0,50 \times 10^{-2}$ & 0,00 & $0,70 \times 10^{-2}$ \\
5 & Transparency $(\mathrm{cm})$ & 0,09 & 0,25 & 0,42 \\
6 & BOD $\left(\mathrm{mg} \cdot \mathrm{L}^{-1}\right)$ & 0,69 & 1,96 & 1,30 \\
7 & $\mathrm{Alkalinity}\left(\mathrm{mg} \cdot \mathrm{L}^{-1}\right)$ & 1,44 & 2,66 & 1,78 \\
8 & $\mathrm{Hg}$ of liver $\left(\mathrm{mg} \cdot \mathrm{L}^{-1}\right)$ & 2,34 & 6,11 & 2,04 \\
9 & $\mathrm{TSS}\left(\mathrm{mg} \cdot \mathrm{L}^{-1}\right)$ & 2,22 & 6,15 & 2,55 \\
10 & $\mathrm{Hg} \mathrm{of} \mathrm{worm}\left(\mathrm{mg} \cdot \mathrm{L}^{-1}\right)$ & 4,45 & 13,27 & 2,86 \\
11 & Depth $(\mathrm{m})$ & 39,78 & 76,88 & 3,19 \\
12 & $\mathrm{NH}\left(\mathrm{mg} \cdot \mathrm{L}^{-1}\right)$ & 85,03 & 98,70 & 3,81
\end{tabular}




\section{I Macrothink}

Aquatic Science and Technology

ISSN 2168-9148

2014, Vol. 2, No. 1

\begin{tabular}{lllll}
13 & $\mathrm{Hg}$ of snail $\left(\mathrm{mg} \cdot \mathrm{L}^{-1}\right)$ & 11,97 & 27,37 & 4,24 \\
14 & $\mathrm{DO}\left(\mathrm{mg} \cdot \mathrm{L}^{-1}\right)$ & 242,63 & 382,13 & 5,88 \\
15 & $\mathrm{pH}$ & 129,95 & 180.47 & 6,42 \\
\hline
\end{tabular}

BOD, alkalinity, and $\mathrm{Hg}$ in climbing perch liver, TSS, $\mathrm{Hg}$ in worm's body, depth level, $\mathrm{NH}_{3}$, $\mathrm{Hg}$ in snail's body, DO, and $\mathrm{pH}$ based on classification of water quality status were included in class B in rate between $1.0<\mathrm{IP} \leq 5.0$ (错误 ! 未找到引用源。). The status of water quality at Cempaka gold mining area was mildly polluted. $\mathrm{DO}$ and $\mathrm{pH}$ in the range $5.0<\mathrm{IP} \leq 10$ with the criteria being moderately polluted. In the mining area, the water quality status of Cempaka diamond and gold IP, based on eight parameters measured, was mildly polluted.

\subsection{Damage of Climbing Perch Liver Tissue}

Observation result of liver hispathology on climbing perch showed that there were some damage such as inflammation (Figure 3), cloudy swelling (Figure 4), hemorrhage (

Figure 2), focal necrosis and hepatoma (Figure 5). The identification result and damage level of climbing perch liver tissue can be seen in Table 3. Hispathology observation can be seen at Figure 2 to Figure 5.

Table 3. Identification and percentage of tissue damage on liver Climbing perch

\begin{tabular}{lllll}
\hline \multirow{2}{*}{ No } & Type of damage & Observation & & \\
\cline { 3 - 5 } & & $\mathbf{1}$ & $\mathbf{2}$ & $\mathbf{3}$ \\
\hline 1 & Inflammation & +++ & ++ & + \\
2 & Cloudy swelling & + & ++ & +++ \\
3 & Focal necrosis & ++ & + & + \\
4 & Karyolitic & + & + & + \\
5 & Hemorrhage & - & + & - \\
6 & Hepatoma & +++ & - & - \\
\hline Cell total & 317 & 177 & 117 \\
\hline Percentage $(\%)$ & 72,55 & 46,89 & 88,03 \\
\hline
\end{tabular}

Notes: None (-), mild (+), moderate $(++)$, severe $(+++)$.

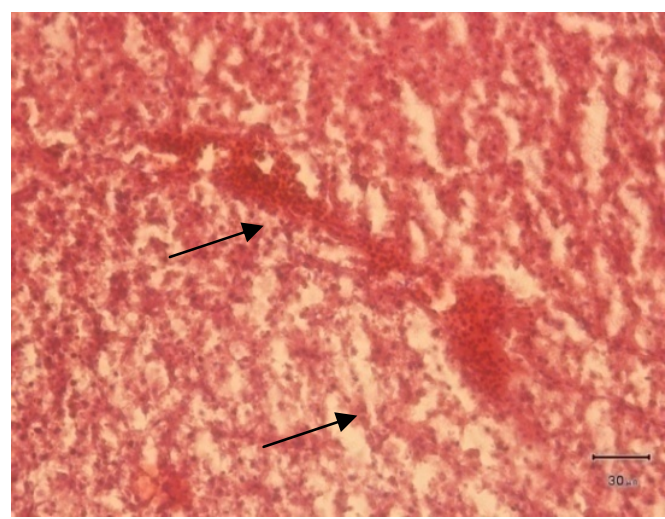

Figure 2. Section of the liver of climbing perch, showing hemorrhage (arrows). HE 400x 


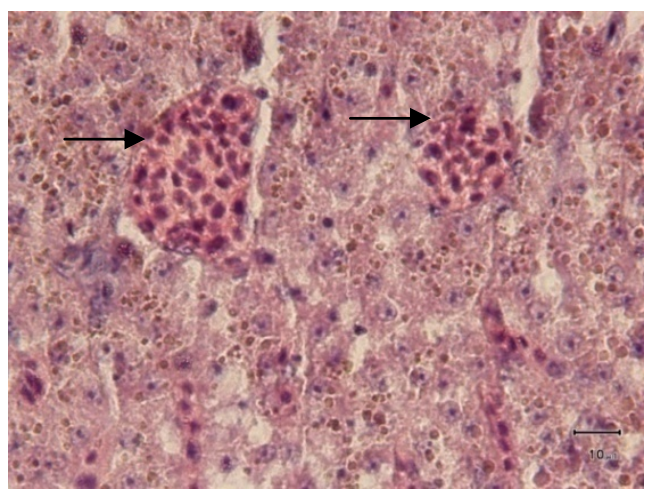

Figure 3. Section of the liver of climbing perch, showing inflammation (arrows). HE 400x

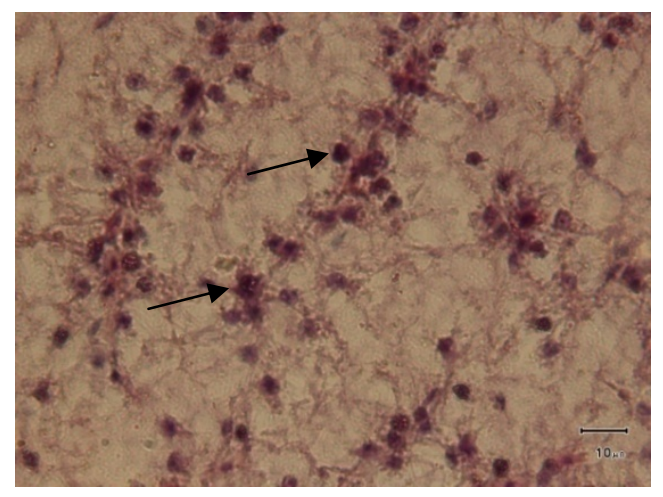

Figure 4. Section of the liver of climbing perch, showing cloudy swelling (arrows). HE 400x

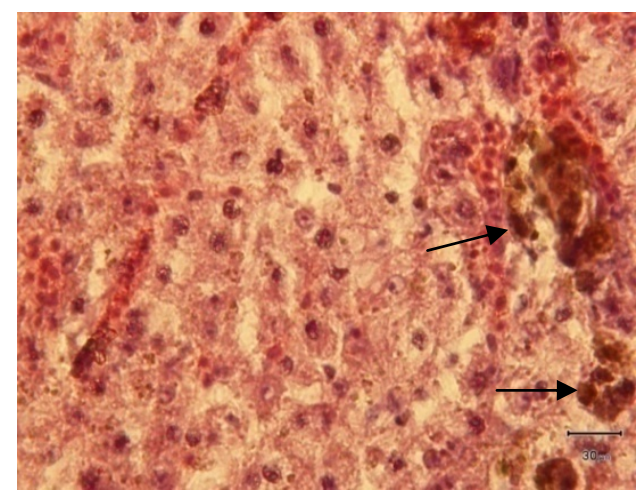

Figure 5. Section of the liver of climbing perch, showing hepatoma (arrows). HE 400x

$\mathrm{Hg}$ content in climbing perch liver at Site $3 \mathrm{PT}$ Galuh Cempaka was about $0.110 \mathrm{mgL}^{-1}$. It was measured without hispathology observation. $\mathrm{Hg}$ at Site 1, Murung Village, was about $0.038 \mathrm{mg} \cdot \mathrm{L}^{-1}$. The content showed that $\mathrm{Hg}$ passed the allowed level. This was proved through hispathology observation by noting damage such as inflammation (Figure 3), cloudy swelling (Figure 4), focal necrosis, and karyolitic. Damage percentage in liver tissue of climbing perch was about $88.03 \%$ (at Site 3), while there was bad damage of $72.55 \%$ at Site 1 . Damage on 
climbing perch liver tissue can be seen as an indicator of water pollution which is caused by the increase of $\mathrm{Hg}$ in water, fishes live, and fishes liver tissue. This is the main reason of why liver, instead of other fishes organs, is always being an indicator of water (Reddy, et al., 2012; Reddy, et al., 2011; Pugazhvendan, 2009; Nicula, 2009).

Through hispathology observation, low concentration of $\mathrm{Hg}$ and high concentration in climbing perch liver showed physiological change which later may harms the tissue of fishes liver. Based on pollution index, Cempaka gold mining activity indicated mildly polluted. Damage of tissue was around 50-80\% (Table 3). Generally, types of damage found were inflammation (Figure 3), cloudy swelling (Figure 4), focal necrosis, karyolitic, hemorrhagic (

Figure 2), and hepatoma (Figure 5) with severe of damage. Therefore, climbing perch liver could be applied as biomarker and an indicator of water pollution at Cempaka mining.

\section{Conclusion}

The finding showed that the water quality in Cempaka diamond and gold mining area was classified in Class B described by GRME Republic of Indonesia, No 115/2003. Status with level of pollution index around $0 \leq \mathrm{IP} \leq 5.0$. Based on the pollution index status, the water quality at Cempaka diamond and gold mining area was mildly polluted with the tissue damage around $50-80 \%$, which was considered as hard damage level.

\section{References}

Ademoroti, C. M. A. (1996). Standard methods for water and effluents analysis (pp. 1-49). Foludex Press Ltd: Ibadan, Nigeria.

Afshar, S., Farshid, A. A., Heidari, R., \& Ilkhanipour, M. (2008). Histopathological changes in the liver and kidney tissues of Wistar albino rat exposed to fenitrothion. Toxicology and Industrial Health, 24, 581-586. http://dx.doi.org/10.1177/0748233708100090

Ahmed, A. (2004). Ecological studies of the River Padma at Mawa Ghat, Munshiganj I. Physicochemical properties. Pakistan Journal of Biological Sciences, 7(11), 1865-1869. http://dx.doi.org/10.3923/pjbs.2004.1865.1869

Akter, M. S., Ahmed, K., Akhand, A., \& Islam, M. A. (2008). Acute toxicity of Arsenic and Mercury to fresh water climbing perch, Anabas testudineus (Bloch). World Journal of Zoology, 3(1), 13-18.

Alabaster, J. S., \& Lloyd, R. (1980). Water quality criteria for freshwater fish. Food and Agricultural Organization of United Nations. Butterworths London-Boston.

Altun, O., Sacan, M. T., \& Erdem, A. K. (2009). Water quality and heavy metal monitoring in water and sediment samples of Küçükçekmece lagoon Turkey (2002-2003). Environment Monitoring Assessment, 151, 345-362. http://dx.doi.org/10.1007/s10661-008-0276-8

APHA (American Public Health Association). (1998). Standard methods for the examinations of water and wastewater (20th Ed) APHA, AWWA (American Water Works Association) and WEF (Water Environment Federation). United Book Press: Inc. Maryland, US.

Belger, L., \& Rider, F. B. (2006). Factors controlling mercury levels in two predatory fish 
species in the Negro river basin, Brazilian Amazon. Science of the Total Environment, 367, 451-459. http://dx.doi.org/10.1016/j.scitotenv.2006.03.033

Boyd, C. E. (1988). Water quality in warmwater fish ponds. Fourth Printing Auburn Univ. Agricultural Experiment Station, Alabama. USA.

Boyd, C. E., \& Lichkoppler. (1991). Water quality management on fish pond. Direktorat Jenderal Perikanan, Jakarta.

Campbell, L. (2010). Environmental toxicology and chemistry of mercury. ENSC 2010: Mercury Ecotoxicology and Contaminants. School of Environmental Studies and Department of Biology.

Carrola, J., Fernandes, A. F., Matos, P., \& Rocha, E. (2009). Liver hispathology in Brown Trout (Salmo trutta f. fario) from the Tinhela River, subjected to mine drainage from Abandoned Jales Mine (Portugal). Bulletin of Environmental Contamination Toxicology, 83, 35-41. http://dx.doi.org/10.1007/s00128-009-9726-4

CCME (Canadian Council of Minister of Environment). (2000). Canadian tissue residue guidelines for the protection of wildlife consumers of aquatic biota. In: Canadian environmental quality guidelines, 1999, Canadian Council of Ministers of the Environment, Winnipeg.

Cui, L. F., Huang, Z. F., Liu, Z. W., \& Fu, M. X. (2008). Relationships between chlorophyll a and $\mathrm{pH}$, dissolved oxygen in algal bloom water. Water and Wastewater Engineering (Supplement), 34(1), 177-178.

Davies, A. B. S., Bloom, \& Hee, S. S. Q. (1997). The environmental geochemistry and bioaccessibility of mercury in soils and sediments. A Review Risk Analysis, 17, 557-569. http://dx.doi.org/10.1111/j.1539-6924.1997.tb00897.x

Davis, M. L., \& Masten, S. J. (2004). Principles of environmental engineering and science. Boston, US: MacGraw Hill.

Di Giulio, R. T., \& Hinton, D. E. (2008). The Toxicology of fishes (pp. 632-884). Taylor \& Francis. http://dx.doi.org/10.1201/9780203647295

Drevnick, P. E., \& Roberts, A. P. (2008). Mercury toxicity in livers of northern pike (Esox lucius) from Isle Royale, USA. Comparative Biochemistry and Physiology: Part C, 143(3), 331-338.

Driscoll, C. T., Han, Y. J., Chen, C. Y., Evers, D. C., Lambert, K. F., \& Holsen, T. M. (2007). Mercury contamination in forest and freshwater ecosystems in the Northeastern United States. Bioscience, 57(1), 17-28. http://dx.doi.org/10.1641/B570106

Effendi, H. (2003). Study of water quality of the resource management and aquatic environments. Kanisius Press: Yogyakarta.

Fernandes, C, Fonta1'nhas-Fernandes, A., Rocha, E., \& Salgado, M. A. (2008). Monitoring pollution in Esmoriz-Paramos lagoon, Portugal: Liver histological and biochemical effects in 
Liza saliens. Environmental Monitoring and Assessment, 145, 315-322. http://dx.doi.org/10.1007/s10661-007-0041-4

Gianni, A., Kehayias, G., \& Zacharias, I. (2012). Temporal and spatial distribution of physico-chemical parameters in an anoxic lagoon, Aitoliko, Greece. Journal of Environment Biology, 33, 107-114.

GRME (Government Regulation of the Ministry of Environment). (2003). GRME No: 115/ 2003 on guidelines for the determination of water quality status, 683-704.

GRRI (Government Regulation of Republic Indonesia). (2001). GRRI No. 85/2001 about the management of water quality and water pollution control.

Hall, B. D., Bodaly, R. A., Fudge, R. J. P., Rudd, J. W. M., \& Rosenberg, D. M. (1997). Food as the dominant pathway of methylmercury uptake by fish. Water, Air, and Soil Pollution, $100,13-24$.

Hammond, D., Gond, V., de Thoisy, B., Forget, P., \& DeDijn, B. (2007). Causes and consequences of a tropical forest gold rush in the Guiana Shield, South America. Ambio, 36(8), 661-670. http://dx.doi.org/10.1579/0044-7447(2007)36[661:CACOAT]2.0.CO;2

Haschek, W. M., Walling, M. A., \& Rousseaux, C. (2010). Fundamental of toxicologic pathology (pp. 211-686). New York, NY: Academic Press.

Hilson, G., \& Vieira, R. (2007). Challenges with minimizing mercury pollution in the small-scale gold mining sector. Experiences from the Guiana. International Journal of Environmental Health Research, 17(6), 429-441. http://dx.doi.org/10.1080/09603120701633396

Howard, J., Trotz, M. A., Thomas, K., Omisca, E., Chin, H. T., Halfhide, T., \& Stuart, A. L. (2011). Total mercury loadings in sediment from gold mining and conservation areas in Guyana. Environmental Monitoring and Assessment, 179, 555-573. http://dx.doi.org/10.1007/s10661-010-1762-3

Iyabu, H. (2008). Analysis of levels of mercury (Hg) in the River District Taluduyunu Marisa Pohuwato. Journal of Research and Education, 5(2), 88-92.

Kalay, M., \& Camli, M. (2000). Elimination of essential (Cu, Zn) and non-essential (Cd, PB) metals from tissues of freshwater fish Tilapia zilli. Turkish Journal of Zoology, 24, 429-436.

Karadede, H., Oymak, S. A., \& U“nlu“, E. (2004). Heavy metals in mullet (Liza abu), and catfish, (Silurus triostegus), from the Atatu"rk Dam Lake (Euphrates), Turkey. Environment International, 30, 183-188. http://dx.doi.org/10.1016/S0160-4120(03)00169-7

Kim, Y. E. N., Powell, \& Ashton, K. A. (2006). Hispathology analysis. In: Histological Technique for Marine Bivalve Mollusca (pp. 19-52). Update NOAA Tech. Mem. NOS NCCOS 27, Silver Spring.

Kolawole, O. M., Ajayi, K. T., Olayemi, A. B., \& Okoh, A. I. (2011). Assessment of water quality in Asa River (Nigeria) and its indigenous Clarias gariepinus fish. International 
Journal Environment of Research and. Public Health, 8, 4332-4352. http://dx.doi.org/10.3390/ijerph8114332

Krabbenhoft, D. P. (1996). Summary document for the USGS workshop on mercury cycling in the environment. US Geological Survey, Water Resource Divisions. Retrieved from http://wwwrvares.er.usgs.gov/toxics/pubs/hg/summary.shtml.

Kuparinen, A., Cano, J. M., Loehr, J., Herczeg, G., Gonda, A., \& Merila, J. (2011). Fish age at maturation is influenced by temperature independently of growth. Oecologia, 167, 435-443. http://dx.doi.org/10.1007/s00442-011-1989-x

Lasut, M. T., Yasuda, Y., Edinger, E. N., \& Pangemanan, J. M. (2010). Distribution and accumulation of mercury derived from gold mining in marine environment and its impact on residents of Buyat Bay, North Sulawesi, Indonesia. Water Air Soil Pollution, 208, 153-164. http://dx.doi.org/10.1007/s11270-009-0155-0

Mandal, P., Upadhyay, R., \& Hasan, A. (2010). Seasonal and spatial variation of Yamuna River water quality in Delhi, India. Environmental Monitoring and Assessment, 170, 661-670. http://dx.doi.org/10.1007/s10661-009-1265-2

Mendil, D., Demirci, Z., Tuzen, M., \& Soylak, M. (2010). Seasonal investigation of trace element contents in commercially valuable fish species from the Black sea, Turkey. Food and Chemical Toxicology, 48, 865-870. http://dx.doi.org/10.1016/j.fct.2009.12.023

MHR (The Ministry of Health Regulation). (1990). MHR No: 416/Men-Kes/Per/IX/1990 about the requirements and water quality monitoring.

Michael, P. (1984). Ecological methods for field and laboratory investigation (pp. 1-152). Tata McGraw-Hill Publishing Company Limited.

Nartey, V. K., Klake, R. K., Hayford, E. E., Doamekpor, L. K., \& Appoh. E. K. (2011). Assessment of Mercury Pollution in Rivers and Streams around Artisanal Gold Mining Areas of the Birim North District of Ghana. Scientific Research Journal of Environmental Protection, 2, 1227-1239. http://dx.doi.org/10.4236/jep.2011.29141

Nicula, M., Negrea, P., Gergen, I., Harmanesceu, M., Gogoasa, I., \& Lunca. (2009). Mercury bioaccumulation in tissue of fresh water fish Carassius auratus gibello (silver crusian carp) after mercury intoxication. Lucrari stintificeSeria Zootechnie, 52, 676-679.

NRC (Natural Resources Canada). (1996). Comparison of result from alternative acute toxicity test with rainbow trout selected mine effluents. Prepared in conjunction with CANMET and AETE.

NRC (Natural Resources Canada). (1998). Evaluation of toxicity reduction evaluation (TRE) and toxicity identification evaluation (TIE) application to the Canadian Mining Industry: Prepared by: L. Novak, R. Roy and K. Holtze, ESG International.

OATA (Ornamental Aquatic Trade Association.). (2008). Water quality criteria.

Olojo, E. A. A. (2005). Hispathology of the gills and liver tissues of the African catfish 
Clarias gariepinus exposed to lead. African Journal of Biotechnology, 4(1), 117-122.

Petcoff, G. M., Diaz, A. O., Escalante, A. H., \& Goldemberg, A. L. (2006). Histology of the liver of Oligosarcus jenynsii (Ostariophysi, Characidae) from Los padres Lake, Argentina.

$\begin{array}{llll}\text { Iheringia, } \quad \text { Scr. } & \text { Zool., } & \text { Poto } & \text { Alegre, }\end{array}$

http://dx.doi.org/10.1590/S0073-47212006000200010

Peterson, G. D., \& Heemskerk, M. (2001). Deforestation and forest regeneration following small-scale gold mining in the Amazone. The case of Suriname. Environmental Conservation, $2,117-126$.

Pugashvendan, S. R., Narendiran, N. J., Kumaran, R. G., \& Alagappan, K. M. (2009). Effect of malathion toxicity in the freshwater fish, Ophiocephalus punctatus - A histological and histochemical study. World Journal Fish and Marine Science, 1(30), 218-2224.

Reddy, S. J. (2012). Cadmium effect on histo-biomarkers and melano-macrophage centers in liver and kidney of Cyprinus carpio. World Journal of Fish and Marine Sciences, 4(2), 179-184.

Reddy, S. J., Kiran, R. T., \& Reddy, D. C. (2011). Influence of heavy metals on biochemical and metabolic biomarkers of Indian Major Carp. Labeo rohita. The Bioscan, 6(1), 167-173.

Risjani, Y., Musliha, S., Hermawati, A., Couteau, J., \& Minier, C. (2012). Assessmet of fish health status in the Brantas River, Indonesia. Comparative Biochemistry and Physiology Part A: Molecular \& Integrative Physiology, $163, \quad$ S42. http://dx.doi.org/10.1016/j.cbpa.2012.05.125

Safahieh, A., Hedayati, A., Savari, A., \& Marammazi, J. G. (2010). Effect of in vitro exposure to mercury chloride on phosphatase enzymes in yellowfin seabream. American-Eurasian. Journal of Toxicological Science, 2, 162-168.

Saiki, M. K., Martin, B. A., May, T. W., \& Alpers, C. N. (2010). Mercury concentrations in fish from a Sierra Nevada foothill reservoir located downstream from historic gold-mining operations. Environmental Monitoring and Assessment, 163, 313-326. http://dx.doi.org/10.1007/s10661-009-0836-6

Sari, A. A., \& Maryam, M. (2012). Mercury concentrations in commercial fish from freshwater and saltwater. Bulletin of Environmental Contamination Toxicology, 88, 162-165. http://dx.doi.org/10.1007/s00128-011-0510-x

Scheuhammer, A. M., Meyer, M. W., Sandheinrich, M. B., \& Murray, M. W. (2007). Effects of environmental methylmercury on the health of wild birds, mammals, and fish. Ambio, 36, 12-18. http://dx.doi.org/10.1579/0044-7447(2007)36[12:EOEMOT]2.0.CO;2

Shastri, Y., \& Diwekar, U. (2008). Optimal control of lake pH for mercury bioaccumulation control. Ecological Modelling, 216, 1-17. http://dx.doi.org/10.1016/j.ecolmodel.2008.03.019

Shreadah, M. A., Ghani, S. A. A., Taha, A. A. E., Ahmed, A. E. M., \& Hawash. H. B. I. 
(2012). Mercury and methyl mercury in sediments of Northern Lakes-Egypt. Journal of Environmental Protection, 3, 254-261. http://dx.doi.org/10.4236/jep.2012.33032

SKGR (South Kalimantan Governor's Regulation). (2007). SKGR No. 04/2007 about on wastewater quality standard South Kalimantan Province.

SKGR (South Kalimantan Governor's Regulation). (2007). SKGR No. 05/2007 about on the designation of the river in the province of South Kalimantan and on river water quality standards in the Province of South Kalimantan.

Suckcharoen, S., \& Lodenius, M. (1980). Reduction of mercury pollution in the vicinity of a caustic soda plant in Thailand. Water, Air and Soil Pollution, 3(3), 221-227. http://dx.doi.org/10.1007/BF02279548

Takahara, T., Yamanaka, H., Suzuki, A. A., Horijo, M. N., Ito, T., \& Kawabata, Z. (2011). Stress response to daily temperature fluctuations in common carp. Cyprinus carpio L. Hydrobiologia, 675, 65-73. http://dx.doi.org/10.1007/s10750-011-0796-z

Takashima, F., \& Hibiya, T. (1995). An atlas of fish histology: Normal and pathological features (2nd ed). Tokyo: Kodansha Ltd.

Turekian, K. K., \& Wedepohl, K. H. (1961). Distribution of the elements in some major units of the Earth's crust. Geological Society of America Bulletin, 72(2), 175-192. http://dx.doi.org/10.1130/0016-7606(1961)72[175:DOTEIS]2.0.CO;2

Velcheva, I., Tomova, E., Arnaudova, D., \& Arnaudov, A. (2010). Morphological investigation on gills and liver of freshwater fish from dam lake "student kladenets". Bulgarian Journal of Agricultural Science, 16(3), 364-368.

Wedenmeyer, G. A. (1996). Physiology of fish in intensive culture systems. Chapman and Hall. International Thompson Publ., N.Y.

You, L., Cui, L. F., Liu, Z. W., Yang, B., \& Huang, Z. F. (2007). Correlation analysis of parameters in algal growth. Environmental Science \& Technology, 30(9), 42-44.

\section{Copyright Disclaimer}

Copyright reserved by the author(s).

This article is an open-access article distributed under the terms and conditions of the Creative Commons Attribution license (http://creativecommons.org/licenses/by/3.0/). 